\title{
MEWUJUDKAN MILENIAL BIJAK SADAR PAJAK DI MASA PANDEMI COVID-19
}

\author{
Ferry Irawan ${ }^{1}$, Bintang Septian Simbolon ${ }^{2}$, Caesario Santo H. Gultom ${ }^{3}$, Dhea Monica Rudi ${ }^{4}$, Ebsan \\ Tangguh Septino ${ }^{5}$, Esti Marintan Sianturi ${ }^{6}$, Grace Shelpia Maduma Manik ${ }^{7}$, Karina Deriska ${ }^{8}$, Muhammad \\ Hammam Rafati Lubis ${ }^{9}$, Perdana Ratus Mangiring Sinaga ${ }^{10}$, Tania Naftali Sianturi ${ }^{11}$
}

\author{
1)ferry.irawan@pknstan.ac.id, Politeknik Keuangan Negara STAN \\ * untuk penulis korespondensi
}

\begin{abstract}
The young generation, including millennials, is an important component in national development. Millennials can occupy important positions in the future. Therefore, the level of knowledge and awareness of taxes is a strategic and important thing to understand. Community Service Activities through this web seminar (webinar) aim to provide millennials with tax literacy. The materials presented in the webinar include basic tax concepts, types of taxes, misconceptions about taxes, and the importance of being aware of taxes for the millennial generation. There are several steps involved in the implementation of this webinar. First, the presentation from the resource person. Second, it was followed by a good discussion through the chat box. Third, game activities. At the end of the event there are prizes for active participants. Based on feedback from webinar participants, this activity increases the knowledge and understanding of the participants regarding taxes.
\end{abstract}

Keywords: Millenials, tax awareness, national development

\begin{abstract}
Abstrak
Generasi muda termasuk kaum milenal merupakan salah satu komponen penting dalam pembangunan nasional. Milenial dapat menduduki posisi yang penting di masa depan. Oleh karena itu, tingkat pengetahuan dan kesadaran terhadap pajak menjadi hal yang strategis dan penting untuk dipahami. Kegiatan Pengabdian kepada Masyarakat melalui web seminar (webinar) ini bertujuan untuk memberikan literasi mengenai pajak kepada milenial. Materi yang disampaikan dalam webinar antara lain konsep dasar pajak, jenis pajak, miskonsepsi tentang pajak, dan pentingnya sadar pajak bagi generasi milenial. Terdapat beberapa tahapan yang dilakukan dalam dalam pelaksanaan webinar ini. Pertama, pemaparan dari narasumber. Kedua, dilanjutkan dengan diskusi melalui chat box. Ketiga, kegiatan games. Di akhir acara terdapat hadiah bagi peserta yang aktif. Berdasarkan umpan balik dari peserta webinar, kegiatan ini menambah pengetahuan dan pemahaman para peserta terkait pajak.
\end{abstract}

Kata Kunci : Milenial, sadar pajak, pembangunan bangsa

\section{PENDAHULUAN}

Pajak merupakan hal yang sangat dekat dengan kehidupan kita sehari-hari. Akan tetapi, masih banyak masyarakat Indonesia yang belum paham bahkan tidak tahu dengan sistem perpajakan di Indonesia, terutama generasi milenial yang merupakan kelompok demografi yang mendominasi usia produktif di Indonesia (Prasarti \& Prakoso, 2020). Hal ini terlihat dari literasi pajak generasi milenial Indonesia yang masih rendah sehingga menimbulkan banyaknya miskonsepsi terkait pajak.

Literasi yang minim dan miskonsepsi yang ada menimbulkan sebuah masalah, yaitu kesadaran pajak yang rendah. Masyarakat dengan kesadaran pajak yang rendah cenderung mengabaikan kewajiban perpajakannnya (Taufiqurrahman, et al., 2021). Tidak mengejutkan apabila realisasi penerimaan pajak di Indonesia masih belum mencapai target (Direktorat Jenderal Pajak, 2020). Oleh karena itu, masyarakat perlu diberikan pemahaman yang lebih mendasar mengenai perpajakan kepada masyarakat, khususnya generasi milenial.

Kesadaran pajak yang baik dapat mengoptimalkan penerimaan pajak (Valianti et al., 2021). Salah satu cara untuk membangun kesadaran pajak adalah dengan melakukan sosialisasi dan pelatihan untuk meningkatkan pengetahuan perpajakan bagi generasi muda (Puspanita $e t$ $a l .$, 2020). Hal ini penting dilakukan mengingat Indonesia akan menikmati bonus demografi 


\section{PENGMASKU}

Volume 1 No. 2, Desember 2021

yang ditandai dengan melimpahnya penduduk usia kerja, yakni generasi milenial itu sendiri (Maryati, 2015).

Berangkat dari latar belakang tersebut, seluruh komponen bangsa termasuk civitas akademika dapat berkontribusi kepada negara dalam meningkatkan literasi pajak dan kesadaran masyarakat akan pentingnya pajak (Putra \& Sujana, 2021). Adapun wujud kontribusi yang dilakukan terkait literasi adalah mengadakan webinar. Judul webinar yang diangkat adalah "Mewujudkan Milenial Bijak Sadar Pajak". Dengan judul yang singkat dan padat, peserta bisa menggambarkan seperti apa webinar yang akan diikuti. Pemilihan kata "Milenial" bertujuan bahwa peserta webinar lebih difokuskan kepada generasi yang masih muda, sehingga suasana webinar ini bisa lebih informal dan menggunakan bahasa yang mudah dimengerti. Pemilihan kata "Bijak" menunjukkan pemahaman terhadap suatu hal. Webinar ini bertujuan untuk meningkatkan literasi. Generasi yang bijak adalah generasi yang memahami konsep perpajakan yang sebenarnya dengan harapan pemahaman tersebut dapat membentuk pola pikir dan karakter yang positif bagi para generasi milenial. Hal ini dalam rangka menciptakan suatu budaya yang melekat dan rasa bangga dalam membayar pajak. Kami menggunakan aplikasi video conference berupa aplikasi Zoom dalam pelaksanaan webinar karena aplikasi tersebut cukup populer dan mudah digunakan (Irawan, 2021; Firmansyah et al., 2021a; Firmansyah, et al., 2021b).

Secara spesifik, tujuan pengabdian kepada masyarakat ini adalah memberikan pemahaman kepada generasi muda khususnya kaum milenial mengenai pentingnya pajak bagi seluruh komponen bangsa. Dalam sepuluh sampai dua puluh tahun ke depan kaum milenial merupakan pemimpin dan menjadi motor penggerak pembangunan nasional. Oleh karena itu peningkatan kesadaran sejak dini atas pajak menjadi hal yang sangat strategis (Rahmi et al., 2021). Di bagian berikutnya, akan dijelaskan metode pelaksanaan, hasil dan pembahasan, serta simpulan.

\section{METODE PELAKSANAAN}

Kegiatan pengabdian kepada masyarakat ini dilakukan dalam bentuk web seminar (webinar) melalui aplikasi video conference. Penyelenggara Kegiatan webinar ini civitas akademika Politeknik Keuangan Negara STAN yang terdiri dari sepuluh orang mahasiswa dan satu dosen pembimbing. Pelaksanaan pengabdian kepada masyarakat ini diklasifikasikan dalam tiga tahap yaitu tahap persiapan, tahap pelaksanaan dan tahap evaluasi. Pada Tahap persiapan ini dilakukan identifikasi kebutuhan pelatihan oleh pengabdi dan penyelenggara, termasuk di dalamnya juga dibahas target peserta, metode webinar dan capaian dari kegiatan webinar serta pembuatan flyer webinar (Gambar 1).

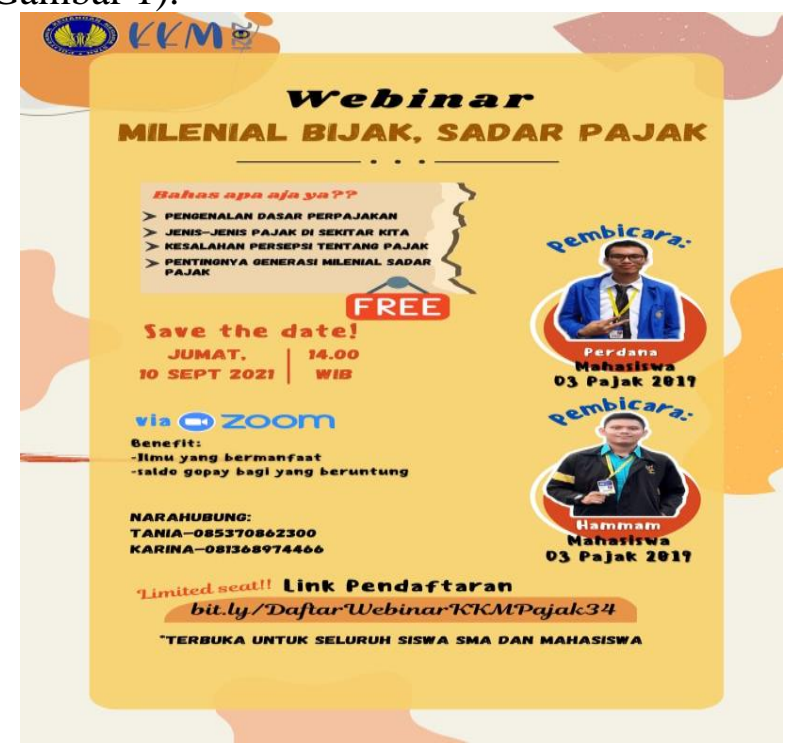




\section{PENGMASKU}

Volume 1 No. 2, Desember 2021

Gambar 1. Flyer webinar

Tahap kedua, yaitu pelaksanaan. Kegiatan webinar dibuka oleh dua orang master of ceremony (MC) merangkap moderator (Gambar 2). Selanjutnya Dua orang narasumber menyampaikan materi dalam durasi lebih kurang 40 menit (Gambar 3).

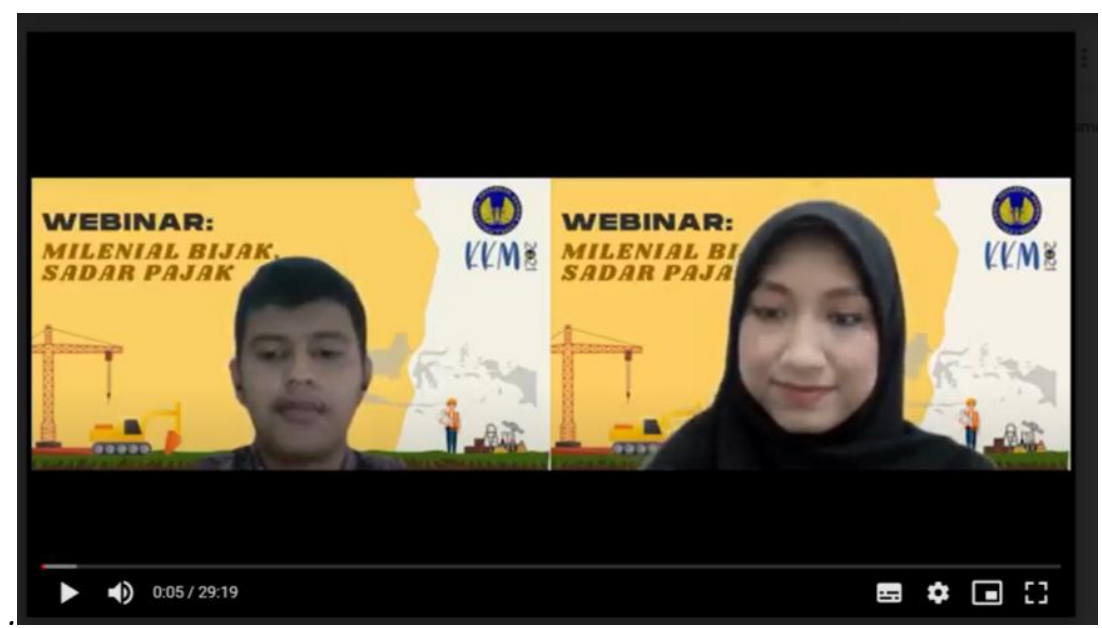

Gambar 2. Pembukaan oleh MC dan Moderator

Selanjutnya pembukaan sekaligus pemberian materi singkat mengenai kegiatan webinar disampaikan oleh dosen pembimbing (Gambar 3).

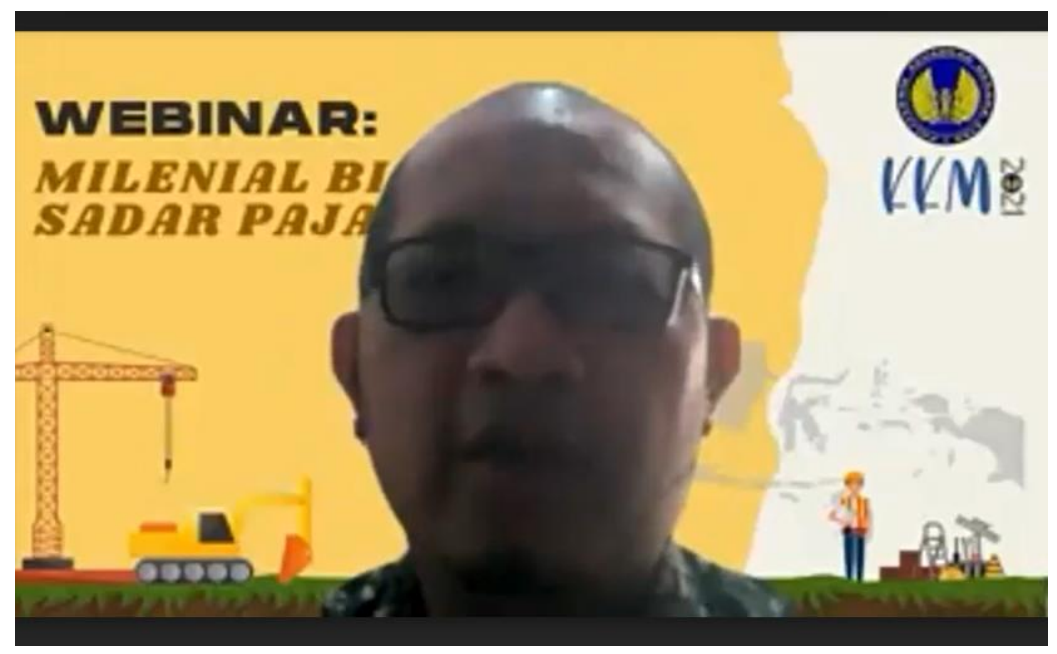

Gambar 3. Pembukaan webinar

Adapun materi yang disampaikan oleh kedua narasumber antara lain pengenalan dasardasar perpajakan, jenis-jenis pajak, miskonsepsi tentang pajak, dan pentingnya milenial sadar pajak (Gambar 4). Diskusi dipandu oleh dua orang moderator. Kegiatan di tahap kedua ini berjalan dengan baik dan tidak ada gangguan dalam jaringan internet. Materi disusun oleh tim penyusun materi yang terdiri dari empat orang mahasiswa. Selanjutnya materi dimaksud direviu oleh satu orang mahasiswa sebelum akhirnya dilakukan reviu final oleh dosen pembimbing. 


\section{PENGMASKU}

Volume 1 No. 2, Desember 2021

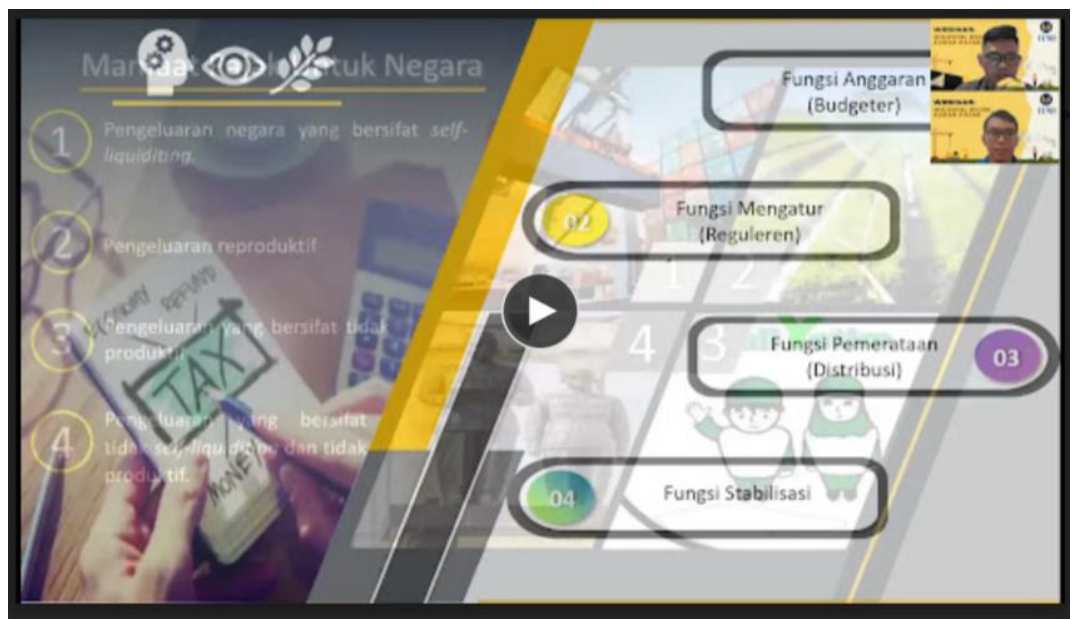

Gambar 4. Penyampaian materi oleh narasumber

Tahap berikutnya adalah evaluasi. Hal ini diindikasikan dengan adanya umpan balik dari para peserta webinar. Evaluasi terbagi menjadi dua bagian yaitu sesi tanya jawab dan games. Pada sesi tanya jawab, para peserta sangat antusias dalam menyampaikan pertanyaan seputar pajak dan pemanfaatan uang pajak. Demikian pula halnya dengan sesi games. Kedua sesi tersebut sangat menarik karena tidak hanya berisi permainan terkait pengetahuan pajak namun juga memberikan hadiah bagi yang mampu menjawab dengan baik. Hadiah berupa uang elektronik senilai Rp 25.000 yang diberikan kepada dua orang penanya terbaik, dan dua orang pemenang games.

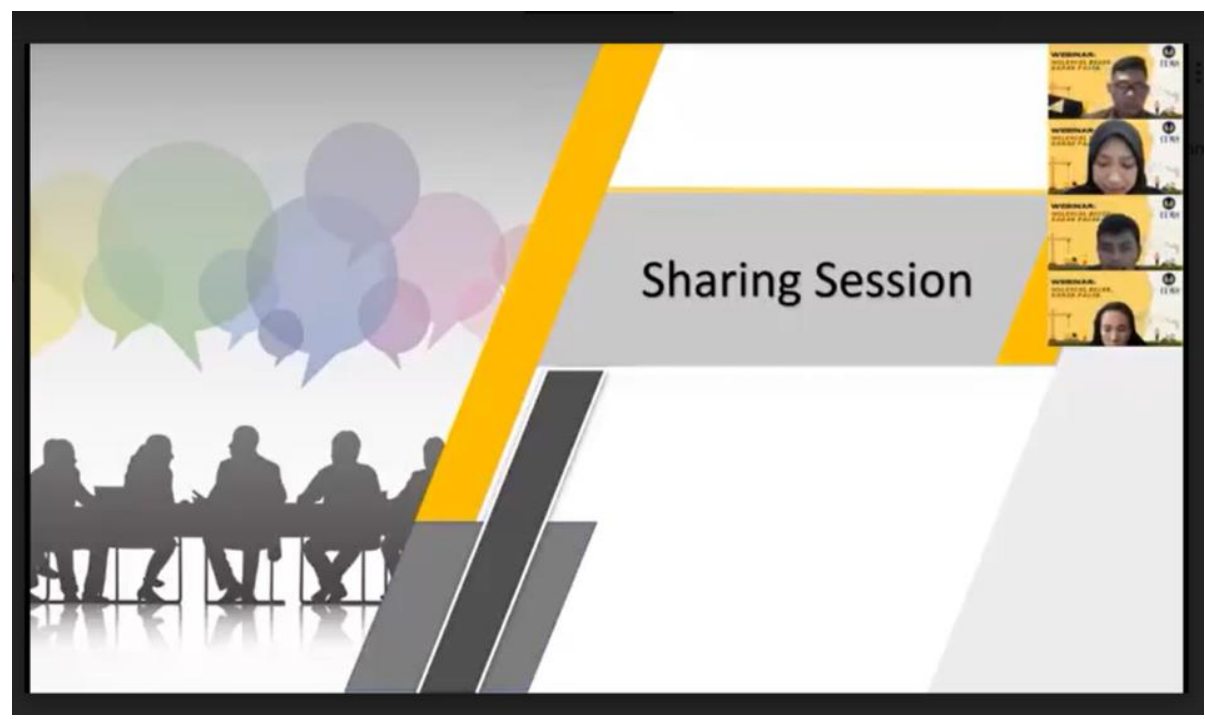

Gambar 5. Sesi tanya-jawab

Total peserta yang mengajukan pertanyaan sebanyak lima orang dengan rincian sebagaimana tercantum dalam Tabel 1.

Tabel 1. Daftar Pertanyaan

\begin{tabular}{|c|l|}
\hline Peserta & \multicolumn{1}{|c|}{ Pertanyaan } \\
\hline 1 & $\begin{array}{l}\text { "Bagaimana dengan adanya pro-kontra mengenai wacana bahwa pajak itu } \\
\text { haram?" }\end{array}$ \\
\hline 2 & $\begin{array}{l}\text { "Apabila saya telah memiliki KTP dan memperoleh penghasilan, apakah wajib } \\
\text { menjadi wajib pajak dan mempunyai NPWP meskipun tinggal dengan orang } \\
\text { tua?" }\end{array}$ \\
\hline
\end{tabular}




\begin{tabular}{|c|l|}
\hline 3 & "Mengapa pajak pusat dan pajak daerah harus dibedakan?" \\
\hline 4 & $\begin{array}{l}\text { "Katanya yang membayar pajak hanya yang mampu saja, sedangkan yang tidak } \\
\text { mampu tidak harus membayar pajak. Bagaimana kriteria mampu dan tidak } \\
\text { mampu?" }\end{array}$ \\
\hline 5 & $\begin{array}{l}\text { "Apakah dengan jumlah penduduk yang banyak akan membuat penerimaan pajak } \\
\text { semakin besar?" }\end{array}$ \\
\hline
\end{tabular}

Setelah sesi tanya-jawab selesai, dilanjutnya dengan sesi permainan (games). Sesi games menggunakan aplikasi "quizziz" agar seluruh peserta webinar dapat mengikuti secara serentak (Gambar 6).

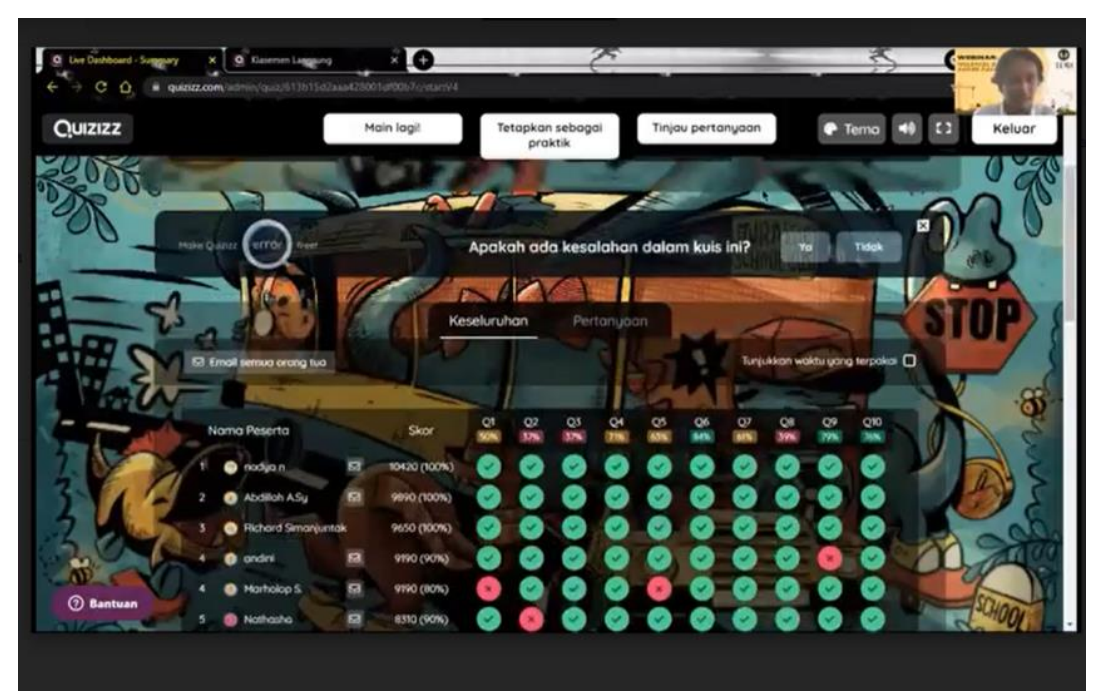

Gambar 6. Sesi games

\section{HASIL DAN PEMBAHASAN}

Webinar diselenggarakan pada hari jumat tanggal 10 September 2021 mulai Pukul 14.00 sampai dengan 16.00 WIB. Kegiatan ini diikuti oleh lebih kurang 50 peserta di ruang zoom conference. Peserta kegiatan ini diikuti oleh pelajar SMA dan mahasiswa dari berbagai wilayah di Indonesia. Sebelum kegiatan dilaksanakan terlebih dahulu menyiapkan flyer untuk disebar ke berbagai sekolah dan perguruan tinggi di Indonesia. Selain itu, dilakukan pula survey kepada 247 responden yang terdiri dari mahasiswa dan pelajar SMA secara acak. survey disebar melalui media sosial instagram pada tanggal 5 - 6 September 2021. Survey bertujuan untuk mengetahui pengetahuan umum terkait pajak. Untuk mencapat tujuan tersebut responden diberikan tiga pertanyaan

Hasil survey dapat diuraikan sebagai berikut. Untuk pertanyaan pertama yaitu "Apakah responden telah mengenal istilah pajak?". Terdapat 183 responden menjawab "sudah mengenal", dan 64 responden menjawab "belum mengenal". Pertanyaan kedua yaitu "Bagaimana tingkat pemahaman anda tentang pajak?". 47 responden menjawab "tidak memadai", 95 responden menjawab cukup memadai", dan 80 responden menjawab "memadai". Sementara itu, terdapat 25 responden tidak memberi jawaban. Pertanyaan terakhir yaitu "Apakah pengetahuan tentang pajak itu penting?". 198 responden menjawab "penting", 24 responden menjawab tidak penting sedangkan 25 responden tidak menjawab.

Pada sesi pemaparan narasumber memaparkan materi dengan topik "Mewujudkan Milenial Bijak Sadar Pajak". Empat hal utama disampaikan oleh narasumber antara lain: pengenalan dasar pajak, jenis-jenis pajak, miskonsepsi tentang pajak, dan pentingnya milenial sadar pajak. Uraian lengkap mengenai materi dapat dijelaskan sebagai berikut. Materi pertama adalah pengenalan dasar pajak. Narasumber menjelaskan berbagai definisi tentang pajak 


\section{PENGMASKU}

Volume 1 No. 2, Desember 2021

termasuk definisi formal yang ada di dalam Undang-Undang Nomor 16 Tahun 2009 tentang perubahan Undang-Undang Nomor 6 Tahun 1983 tentang Ketentuan Umum dan Tata Cara Perpajakan (UU KUP). Berdasarkan UU KUP Pajak adalah kontribusi wajib kepada negara yang terutang oleh orang pribadi atau badan yang bersifat memaksa berdasarkan UndangUndang, dengan tidak mendapatkan imbalan secara langsung dan digunakan untuk keperluan negara bagi sebesar-besarnya kemakmuran rakyat.

Selanjutnya, dijelaskan bahwa terdapat empat fungsi pajak, yaitu (a) fungsi anggaran, yaitu mengumpulkan penerimaan negara melalui mekanisme APBN (Wijaya \& Mahatma, 2017); (b) fungsi mengatur, yaitu pajak dapat digunakan untuk mengatur aktivitas ekonomi tertentu dalam masyarakat seperti pengenaan cukai atas rokok; (c) fungsi distribusi, yaitu pajak merupakan alat untuk mendistribusikan penghasilan dari golongan menengah atas ke golongan menengah bawah; dan (d) fungsi stabilisasi, yaitu pajak sebagai komponen fiskal untuk menstabilisasi perekonomian. Pajak juga memiliki beberapa manfaat, antara lain: penerimaan negara yang bersifat self-liquiditing, pengeluaran yang bersifat reproduktif, pengeluaran yang bersifat tidak produktif, dan pengeluaran yang bersifat tidak self-liquiditing dan tidak produktif. Selanjutnya, dijelaskan pula unsur-unsur yang ada dalam pajak, yaitu: subjek pajak, wajib pajak, objek pajak dan tarif pajak.

Materi kedua adalah jenis-jenis pajak. Pembagian jenis pajak dapat dibagi ke dalam beberapa klasifikasi, antara lain: (a) berdasarkan sistem pemungutannya, (b) berdasarkan sifatnya, dan (c) berdasarkan instansi pemungutnya. Berdasarkan sistem pemungutannya pajak dibedakan menjadi dua yaitu pajak langsung (contoh: Pajak Penghasilan - PPh) dan pajak tidak langsung (contoh: Pajak Pertambahan Nilai - PPN). Berdasarkan sifatnya, pajak dapat dibedakan menjadi pajak objektif (contoh: PPN) dan pajak subjektif (contoh: PPh). Berdasarkan instansi pemungutnya, pajak dibedakan menjadi dua, yaitu pajak yang dipungut oleh pemerintah pusat (contoh: PPh, PPN, bea materai) (Wijaya \& Nirvana, 2021), dan pajak yang dipungut oleh pemerintah daerah (contoh: pajak hotel dan restoran, pajak hiburan, pajak reklame).

Materi ketiga adalah miskonsepsi tentang pajak. Miskonsepsi pajak muncul karena kurangnya literasi di masyarakat (Susilawati et al., 2021). Beberapa ilustrasi miskonsepsi tentang pajak adalah sebagai berikut. Membayar parkir disamakan dengan pajak atas parkir. Selanjutnya, membayar pajak saat makan di restoran dianggap sama dengan membayar PPN. Contoh lainnya adalah anggapan bahwa yang membayar pajak hanya konsumen saja sedangkan pedagang tidak ada kewajiban membayar pajak. Pendapat masyarakat lainnya adalah mengapa negara memajaki sembako (sembilan bahan pokok). Di masa pandemi seperti saat ini harusnya negara tidak mengenakan pajak baik itu PPh atau PPN. Atau, muncul pertanyaan untuk apa membayar pajak jika nanti uang pajak tersebut dikorupsi.

Materi terakhir adalah pentingnya milenial sadar pajak. Generasi muda yang saat ini berusia remaja akan melanjutkan tongkat estafet pembangunan di masa yang akan datang. Oleh karena itu kaum milenial harus memiliki bekal pengetahuan yang memadai termasuk kesadaran akan pajak (Suharsono \& Galvani, 2020). Pajak di Indonesia menjadi pilar utama dalam struktur Anggaran Penerimaan dan Belanja Negara (APBN). Oleh karena itu, seluruh masyarakat termasuk generasi milenial memiliki peran strategis.

Sesi berikutnya adalah tanya jawab. Pertanyaan pertama terkait dengan adanya pandangan bahwa pajak adalah haram. Atas pertanyaan ini respon yang diberikan adalah memberikan pandangan para ulama kontemporer bahwa pajak yang saat ini dipungut pengelolaannya dilakukan oleh pemerintah untuk membiayai pengeluaran yang bersifat umum (Ichsan, 2018) .

Pertanyaan kedua adalah ada kewajiban ber-NPWP (Nomor Pokok Wajib Pajak) bagi orang pribadi yang masih menumpang tinggal dengan orangtua namun telah berpenghasilan. 


\section{PENGMASKU}

Volume 1 No. 2, Desember 2021

Atas pertanyaan ini diberikan respon sebagai berikut. Untuk orang pribadi yang telah memiliki penghasilan di atas batas Penghasilan Tidak Kena Pajak (PTKP) maka telah wajib untuk membayar PPh. NPWP merupakan sebagai sarana administrasi untuk melaporkan besarnya pajak terutang. Namun, bukan berarti kewajiban pajak bergantung pada kepemilikan NPWP.

Pertanyaan ketiga terkait pengelolaan pajak yang terbagi antara pemerintah pusat dan daerah. Respon yang diberikan adalah bahwa pada prinsipnya pajak dikelola oleh negara. Namun, untuk meningkatkan optimalisasi penerimaan untuk kepentingan pembangunan di daerah undang-undang mengatur bahwa daerah juga memiliki kewenangan untuk memungut pajak. Pemungutan pajak tersebut diatur sedemikian rupa sehingga tidak ada duplikasi.

Pertanyaan keempat yang diajukan mengenai apa kriteria mampu dalam membayar pajak. Jawaban yang diberikan oleh narasumber, setiap jenis pajak memiliki kriteria sendiri. Misalnya untuk PPh, kriteria mampu adalah jika ia memiliki penghasilan dengan batasan tertentu sebagaimana diatur dalam peraturan perundang-undangan. Untuk PPN, kriteria mampu adalah saat konsumen mengkonsumsi barang kena pajak dan/atau jasa kena pajak. Secara teknis, terdapat pengaturan lebih lanjut dalam memperhitungkan beban pajak baik PPh maupun PPN. Dalam suatu masa pajak atau tahun pajak, seorang wajib pajak mungkin saja memiliki kelebihan pembayaran pajak atau kekurangan pembayaran pajak.

Pertanyaan terakhir terkait hubungan antara jumlah penduduk dengan jumlah penerimaan pajak. Narasumber menjawab bahwa kondisi idealnya adalah semakin banyak jumlah penduduk akan membuat penerimaan pajak meningkat. Namun dalam praktiknya tidak selalu demikian. Terdapat beberapa faktor dalam peningkatan penerimaan pajak, antara lain: kondisi ekonomi makro, daya beli masyarakat, gaya hidup masyarakat. Selain itu kesadaran dan kepatuhan wajib pajak juga dapat mempengaruhi penerimaan pajak (Oktaviani, et al., 2017).

\section{PENUTUP}

\section{Simpulan}

Umpan balik dari seluruh peserta mengindikasikan bahwa para peserta menjadi lebih mengetahui dan memahami konsep dan ruang lingkup pajak. Selain itu, para peserta menjadi lebih menyadari peran mereka di masa depan. Tantangan untuk membiayai pembangunan nasional ada pada sektor pajak. Kaum milenial di masa depan mungkin ada yang berperan sebagai karyawan, pengusaha, pejabat, teknokrat dan sebagainya. Setiap peran memiliki fungsi masing-masing. Sinergi antara seluruh komponen masyarakat dapat menopang dan mendorong pembangunan secara umum.

\section{Saran}

Keterlibatan peserta dapat ditingkatkan pada kesempatan berikutnya. Selanjutnya, pendekatan dan metode yang digunakan dapat dimodifikasi untuk menarik minat generasi milenial.

\section{DAFTAR PUSTAKA}

Direktorat Jenderal Pajak (2020). Laporan Tahunan 2020: Konsisten Mengoptimalisasi Peluang di Masa Menantang. https://pajak.go.id/sites/default/files/202110/Laporan\%20Tahunan\%20DJP\%202020\%20-\%20Bahasa.pdf

Firmansyah, A., Zulfa, A.M., Prastica, A.E., Nabila, A.A., Aji, A.R.P., Lukyani, C.H., Amallia, E.N., Arifah, L., Andi, M.R., Dewi, N.W.P., Wijaya, R.D., Krisabel, T.T. (2021). Edukasi Akuntansi dan Pelaporan Keuangan UMKM X di Era Pandemi Covid19. Jurnalku, 1(1), 1-7. 


\section{PENGMASKU}

Volume 1 No. 2, Desember 2021

Firmansyah, A., Falembayu, A., Siburian, A.S., Ginting, B.P., Simatupang, C., Putra, K.K., Aisyah, M., Marchelizi, M.A., Siallagan, N., Wibowo, R.H., Ariawan, Y. (2021). Edukasi Literasi Keuangan kepada Kelompok Ibu-Ibu dan Remaja Terkait dengan Jasa Pinjaman Online di Era Pandemi Covid19. Jurnalku, 1(1), 14-21.

Ichsan, N. (2018). Tinjauan penerapan pungutan pajak dan zakat menurut konsep ekonomi islam di Indonesia. Islamadina: Jurnal Pemikiran Islam, 19(2), 75-91.

Irawan, F. (2021). Pelatihan Melalui Web Seminar Dampak UU HPP terhadap Pelaku UMKM Di Era Pandemi. Pengmasku, 1(1), 22-28.

Oktaviani, R.M., Hardiningsih, P., Srimindari, C. (2017). Kepatuhan Wajib Pajak Memediasi Determinan Penerimaan Pajak Penghasilan. Jurnal Akuntansi: 21(2), 318-335.

Prasarti, S., \& Prakoso, E. T. (2020). Karakter dan perilaku milineal: peluang atau ancaman bonus demografi. Consilia: Jurnal Ilmiah Bimbingan dan Konseling, 3(1), 10-22.

Puspanita, I., Machfuzhoh, A., Pratiwi, R., Iii,) D, Ekonomi, F., Bisnis, D., Sultan, U., \& Tirtayasa, A. (2020). Pelatihan dan Pendampingan Pajak UMKM Guna Mendorong Masyarakat Sadar Pajak di Kota Cilegon. Community Development Journal, 1(3), 375382.

Putra, K. V. P., \& Sujana, E. (2021). Pengaruh Kesadaran Wajib Pajak, Pengetahuan Perpajakan dan Kualitas Pelayanan Fiskus Terhadap Kepatuhan Wajib Pajak dalam Membayar Pajak Hotel di Kabupaten Buleleng. Jurnal Akuntansi Profesi, 12(1), 166. https://doi.org/10.23887/jap.v12i1.30824

Rahmi, N., \& Rachmatulloh, I. (2021). Membina UMKM Kota Depok Sadar Pajak Melalui Pelatihan Pengisian SPT Melalui E-filling. Jurnal Komunitas: Jurnal Pengabdian Kepada Masyarakat, 4(1), 48-54.

Sri Maryati, O. (2015). Dinamika Pengangguran Terdidik: Tantangan Menuju Bonus Demografi di Indonesia. Economica: Journal of Economic and Economic Education, 3(2), 124-136.

Suharsono, A., \& Galvani, S. (2020). Optimalisasi Edukasi Perpajakan bagi Generasi Milenial Melalui Video. Scientax: Jurnal Kajian Ilmiah Perpajakan Indonesia, 2(1), 123 -139.

Susilawati, N., Indriani, I., Riana, V., \& Abyan, D. (2021). Tingkat Literasi Pajak Penghasilan Orang Pribadi dan Determinannya (Studi di Jakarta, Bogor, Tangerang, dan Bekasi). Sebatik, 25(1), 286-295. https://doi.org/10.46984/sebatik.v25i1.1288

Taufiqurrahman, T., Resti, Y. M., \& Herawati, H. (2021). Pengaruh Pemahaman Wajib Pajak, Kesadaran Wajib Pajak, Penerapan Sistem e-Filing terhadap Kepatuhan Wajib Pajak (Doctoral dissertation, Universitas Bung Hatta).

Valianti, R. M., Lilianti, E., Darwin, J., \& Saladin, H. (2021). Sadar Pajak Sejak Dini dalam Pendidikan. Jurnal PKM: Pengabdian kepada Masyarakat, 4(2), 130-137.

Wijaya, S. \& Mahatma, E.A. (2017). Analisa Upaya Peningkatan Penerimaan Perpajakan dari Penggalian Potensi Pajak atas Penghasilan Youtuber. Jurnal Manajemen Keuangan Publik, 1(2), 125-130. 


\section{PENGMASKU}

Volume 1 No. 2, Desember 2021

Wijaya, S. \& Nirvana, A.P. (2021). Pajak Pertambahan Nilai Perdagangan Melalui Sistem Elektronik Studi Kasus PT Shopee Internasional Indonesia). Bilancia: Jurnal Ilmiah Akuntansi, 5(3), 245-256. 